\title{
POWOJENNE LOSY ŻOŁNIERZY POLSKICH NA ZACHODZIE (W ŚWIETLE TWÓRCZOŚCI BELETRYSTYCZNEJ PISARZY DRUGIEJ EMIGRACJI)
}

\author{
Jerzy SPEINA (Toruń)
}

Dzieło literackie, takie, które porządkuje zdarzenia w czasie, wykazuje tendencję do uwzględniania $\mathrm{w}$ ich prezentacji tego, co nie mieści się w klasycznym dyskursie historiografii; dyskurs ten opisuje wprawdzie pewien zamknięty, skończony przebieg wydarzeń w sposób bardziej wszechstronny i systematyczny, ale pozbawiony jest napięcia między historią zbiorową a doświadczeniami osobistymi, a także intencji wyznaczenia jakiejś perspektywy egzystencjalnej i psychologicznej dla oceny wielowymiarowości ludzkiego losu. Koncentracja interesujących nas tu przekazów literackich na wysłowieniu myśli i emocji związanych z bezpośrednim, jednostkowym odniesieniem do wypadków co prawda współczesnych, ale stopniowo przechodzących już tak to wygląda z perspektywy drugiej dekady XXI w. — do czasu historycznego, może być powodem, dla którego warto przyjrzeć się owym przekazom bliżej.

Spojrzeniem objęte zostaną powieści i opowiadania (na obrzeżu znalazła się, skromniej reprezentowana, liryka) — utwory ukazujące trudne drogi pokolenia tzw. emigracji żołnierskiej, zmuszonego w wyniku najazdu dwóch zaborczych armii na ziemię polską do jej obrony w kampanii wrześniowej, a później do walki ,za wolność 
naszą i waszą"1 przeciwko niemieckiemu najeźdźcy u boku aliantów zachodnich na różnych frontach, w najniebezpieczniejszych miejscach (pod Narwikiem, Tobrukiem, Monte Cassino, Falaise...) lub w podziemnym ruchu oporu w okupowanej Polsce; po wojnie zaś - do rozproszenia się, z powodów głównie politycznych, po wielu krajach świata i zapuszczania korzeni w ich nie zawsze przyjazny grunt.

Są to dzieła w większości trwale wpisane w panoramę piśmiennictwa powstałego na obczyźnie, choć mniej wybitne (nie przedstawiają sobą różnorodności i skomplikowania zabiegów pisarskich, nie stanowią wyzwania dla zastanych i sprawdzonych już technik literackiego sposobu kreowania rzeczywistości) i nie sytuujące się w centrum życia literackiego emigracji. Ponieważ zamierzam mówić przede wszystkim o ich horyzoncie poznawczym, o zawartości treściowej (ujętej zasadniczo w perspektywie historyczno-socjologicznej), a nie ukształtowaniu językowo-kompozycyjnym czy konwencjach gatunkowo-stylistycznych, wystarczy, jeśli powiem w tym miejscu, że odwołują się one w konstrukcji podmiotu mówiącego najczęściej do postawy uczestnika lub naocznego świadka; że korzystają — jeśli idzie o prozę fabularną — z komentarza wyjaśniającego i oceniającego fakty, który bywa włączany najczęściej w wypowiedź postaci, natomiast w strategiach narracyjnych, służących podkreślaniu przyczynowego, czasowego i przestrzennego układu zdarzeń, sięgają przede wszystkim do tradycji realizmu, niekiedy wzbogaconej technikami reportażu społeczno-obyczajowego i powieści psychologicznej.

Wypada rozpocząć naszą narrację od przypomnienia przełomowych rozstrzygnięć politycznych, które decydująco wpłynęły na dzieje polskiego wychodźstwa wojennego. Otóż po cofnięciu w lipcu 1945 r. przez mocarstwa zachodnie uznania dyplomatycznego rządowi Rzeczypospolitej Polskiej na uchodźstwie, a tym samym usankcjonowaniu Tymczasowego Rządu Jedności Narodowej, ustanowionego poza jakąkolwiek procedurą demokratyczną - co było bezpośrednią konsekwencją układów i zobowiązań jałtańskich — na początku 1946 r. władze brytyjskie podjęły działania mające na celu rozformowanie Polskich Sił Zbrojnych na Zachodzie (PSZ).

Powodem były — podkreśla Rafał Habielski — zarówno kwestie polityczne, to jest naciski na Londyn rządu w Warszawie, jak i względy finansowe. W nocie wystosowanej 14 lutego rząd warszawski oświadczał, że polskie oddziały stacjonujące za granicą nie mogą być uznawane za jednostki Wojska Polskiego i domagał się ich rozwiązania. Niebagatelną rolę odgrywały także pokrywane przez rząd brytyjski koszty utrzymania $\mathrm{PSZ}^{2}$.

Polskie oddziały wojskowe w liczbie prawie 250 tysięcy żołnierzy znajdowały się we Włoszech, Wielkiej Brytanii, Niemczech i na Bliskim Wschodzie. Na półwyspie Apenińskim stacjonował 110-tysięczny 2. Korpus Polski, stanowiący - jak pisze Wojciech Roszkowski -

poważną siłę wojskową i problem polityczny dla rządu angielskiego, tym bardziej że żołnierze i uwielbiany przez nich gen. Anders chcieli utrzymać korpus jako samodzielną, zwartą grupę zdolną do podtrzymywania aktualności sprawy polskiej. [...] Do marca 1946 r. wróciło do kraju zaledwie około 40 tys. żołnierzy. [...] W marcu 1946 r. rząd brytyjski oświadczył, że pragnie powrotu żołnierzy polskich do kraju oraz że ci, którzy

\footnotetext{
${ }^{1}$ Słowa te umieszczono na pomniku poległych żołnierzy 3. Dywizji Strzelców Karpackich na wzgórzu 593 na Monte Cassino (pomniku odsłoniętym 18 VII 1945 r.).

${ }^{2}$ R. Habielski, Życie społeczne i kulturalne emigracji, Warszawa 1999, s. 22 („Druga Wielka Emigracja 1945-1990", t. 3).
} 
uznają to za niemożliwe, będą traktowani w sposób godny ich zasług, choć bez gwarancji prawa pobytu na terenie Imperium Brytyjskiego. 21 III rząd RP zaprotestował przeciw likwidacji PSZ, jednak rząd angielski postanowił przenieść II Korpus z Włoch do Anglii i przesunąć żołnierzy do Polskiego Korpusu Przysposobienia i Rozmieszczenia, tymczasowej organizacji wojskowej w ramach brytyjskich sił zbrojnych, z której mieli być rozsiedlani w miarę powstających możliwości zatrudnienia. [...] Od lipca do października 1946 r. przewieziono wojska II Korpusu do Anglii i rozpoczęto jego rozsiedlanie wraz z innymi jednostkami polskimi na Zachodzie. Do końca 1946 r. ponad 90 tys. żołnierzy PSZ osiedliło się w różnych krajach Europy Zachodniej i Ameryki ${ }^{3}$.

Jeśli idzie o wspomniane przed chwilą względy finansowe, to należy sobie uświadomić, że rząd Wielkiej Brytanii obawiał się przygarnięcia na stałe wielotysięcznej rzeszy imigrantów, gdyż mogło to doprowadzić do nadmiernego obciążenia jego budżetu; zresztą również ludność brytyjska była zaniepokojona, że powojenni przybysze, nie tylko narodowości polskiej, będą jej ,zabierali” pracę, dach nad głową oraz skąpe dobra racjonowane. Do sprawy tej przybliża nas Habielski, powołując się na doniesienia ówczesnej prasy polskiej na wychodźstwie:

Przeciw zatrudnianiu obcokrajowców występowały silne w Wielkiej Brytanii związki zawodowe, nad których zastrzeżeniami rząd labourzystowski nie mógł przechodzić do porządku dziennego. W początku 1947 r. stosowne porozumienia podpisane zostały np. pomiędzy rządem a związkami zawodowymi rolników i robotników rolnych. Brytyjskie ministerstwo pracy uzyskało także zgode związku na zatrudnianie Polaków w górnictwie, przemyśle metalowym, hutnictwie i budownictwie drogowym. Mimo to dochodziło jednak do wysuwania przez regionalne związki poszczególnych branż postulatów sprowadzających status polskich robotników do pracowników drugiej kategorii (np. żądanie zwolnień Polaków w pierwszej kolejności w wypadku ograniczania liczby zatrudnionych) ${ }^{4}$.

\footnotetext{
${ }^{3}$ W. Roszkowski, Historia Polski 1914-1991, Warszawa 1992, s. 169. Co do PKPR: pisał Tymon Terlecki w liście z 12 sierpnia 1946 r. do Kazimierza Wierzyńskiego, że organizacja ta „,nie przewiduje żadnej formy specjalnej dla inteligentów, zaszeregowuje jednakowo wszystkich”, ofiarowując perspektywę pracy fizycznej lub życia w prymitywnym obozie, czyli ,,wegetacji pozbawionej sensu i widoków"; cyt. z: N. Taylor-Terlecka, Nieustający kryzys czytelniczo-wydawniczy. Sytuacja jednego pisarza na marginesie polskiego życia wydawniczego w Londynie, [w:] Katolicki Ośrodek Wydawniczy Veritas w Londynie. Nie zamknięty rozdziat. Studia i szkice, pod red. Z. E. Wałaszewskiego i R. Moczkodana, Toruń-Londyn 2003, s. 71.

${ }^{4}$ R. Habielski, Życie spoteczne i kulturalne, s. 36. Ciekawe dane dotyczące poruszonej tu sprawy znajdziemy w tekście Hanny Świderskiej Polska społeczność w Wielkiej Brytanii 1939_ 1950 (Kultura $1990 \mathrm{nr}$ 1/2/508-509/, s. 184): „Demobilizacja PSZ w Anglii pociągnęła za sobą sprowadzenie na Wyspę rodzin wojskowych rozproszonych po świecie, co miało miejsce w latach 1946-1949, i zakwaterowanie ich w opustoszałych obozach wojskowych. Dla samych tylko rodzin 2 Korpusu przeznaczono 160 obozów. Planowano trzymać w nich Polaków jak najdłużej nie tylko ze względu na kryzys mieszkaniowy, ale żeby te spartańskie warunki zachęciły ich do opuszczenia Anglii. Pod koniec r. 1948 okazało się jednak, że polski ciężar nie jest aż tak straszny, jak się zdawało, bo ze 140.200 Polaków na Wyspie tylko 19,8 \% pozostawało na rządowym utrzymaniu, a reszta przeszła na własny garnuszek. Sprawozdanie PRC [Polish Resettlement Corps] podkreślało korzyści z zatrudnienia Polaków w przemyśle brytyjskim, m.in. i to, że choć należeli do najniżej płatnych robotników niewykwalifikowanych, to jednak (ze względu na bardzo wysoką wśród nich proporcję samotnych mężczyzn) liczba Polaków płacących podatki była ponad przeciętną całej pracującej ludności”. Artykuł stanowi recenzję książki The Formation of the Polish Community in Great Britain 1939-1950 Keitha Sworda (napisanej we współpracy z Normanem Daviesem i Janem Ciechanowskim).
} 
Inne rządy zachodnie też apelowały do przebywających na ich terenie byłych żołnierzy armii sprzymierzonych, aby jak najszybciej udali się do swych domów. Wielu odbiorców tego apelu spośród Polaków (byli wśród nich również uchodźcy cywilni), nieufnych wobec porządku politycznego wprowadzanego nad Wisłą przez komunistów, odmówiło repatriacji. Argument nie do odparcia wysuwali wygnańcy z zabużańskich kresów, którzy w olbrzymiej większości przeszli przez więzienia i obozy sowieckie: nie mieli dokąd i po co wracać, ponieważ na mocy arbitralnych postanowień, powziętych w Jałcie przez przywódców koalicji antyhitlerowskiej, ich domy i ziemie znalazły się poza granicami państwa polskiego. Ostatecznie 90 procent składu 2. Korpusu pozostało na emigracji.

Zdecydować się na powrót do kraju, biorąc pod uwagę związki rodzinne, tęsknotę za bliskimi i potrzebę dopełnienia wobec nich moralnego obowiązku, czy zostawić za sobą wszystko i wybrać tułaczkę na obczyźnie? Na to pytanie, kryjące w sobie splot przesłanek (psychologicznych, moralnych, ideologicznych) muszą sobie samodzielnie odpowiedzieć rozlokowane we Włoszech masy żołnierskie z Amnestii (Drugi rzut $i$ inne opowiadania, Paryż 1968) Czesława Dobka (autor walczył w roku 1944 na froncie włoskim, gdzie dosłużył się stopnia kapitana jako zastępca dowódcy dywizjonu artylerii lekkiej w 5. Karpackiej Dywizji Piechoty; za udział w bitwie pod Monte Cassino został odznaczony Krzyżem Walecznych). Amnestia pokazuje, jak ,wielka polityka" wpływa na małe ludzkie dramaty i konflikty, na konkretne decyzje podejmowane z dnia na dzień. Do wyjazdu nakłania żołnierzy i oficerów ulotka, odwołująca się do ich poczucia patriotycznego; można z niej wyczytać, że dźwigająca się z ruin ojczyzna „potrzebuje pomocy każdego ze swoich synów wobec mozolnego zadania odbudowy kraju oraz zacierania śladów spowodowanych wojną spustoszeń". I wszystko byłoby w porządku, wezwanie to zostałoby chyba przyjęte - gdyby nie umieszczone na jego końcu słowa, jakby dopisane inną ręką, niewykluczone, że przez warszawską misję wojskową: „Dekret amnestyjny z sierpnia 1945 r. będzie stosowany do wszystkich członków Polskich Sił Zbrojnych powracających z zagranicy". Zdumieni takim obrotem sprawy wojskowi nie mogą pojąć, dlaczego ofiarowuje się im amnestię — i próbują dociec, jakiego to dopuścili się przestępstwa, które wymaga wymazania przez krajowy wymiar sprawiedliwości. Major, dowódca dywizjonu artylerii, uważa, iż należy pozostać na Zachodzie i kontynuować walkę zbrojną o wolną i suwerenną Polskę, oczekuje tego bowiem trzydziestu dwóch jego zmarłych podkomendnych, których pochował w piaskach pustyni uzbeckiej. Ich cierpienia i śmierć, ofiarowane, aby inni mogli żyć, nie mogą, jego zdaniem, okazać się daremne.

Dramat zdemobilizowanych żołnierzy, nie widzących dla siebie możliwości reemigracji, uczynił tematem wiersza Powrót (Lata londyńskie, Londyn 1946) Marian Hemar, żołnierz Samodzielnej Brygady Strzelców Karpackich, w roku 1942 odkomenderowany do Londynu do pracy w Ministerstwie Informacji i Dokumentacji, autor znany dobrze z czasów przedwojennych, po wojnie naczelny satyryk emigracji niepodległościowej. $\mathrm{W}$ wierszu przemawia słowami przenikniętymi goryczą $\mathrm{w}$ imieniu zbiorowości, do której sam należy:

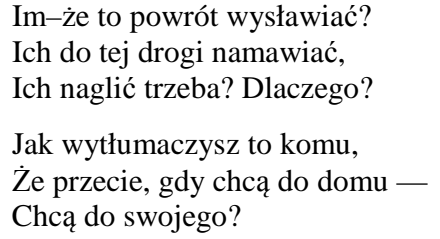




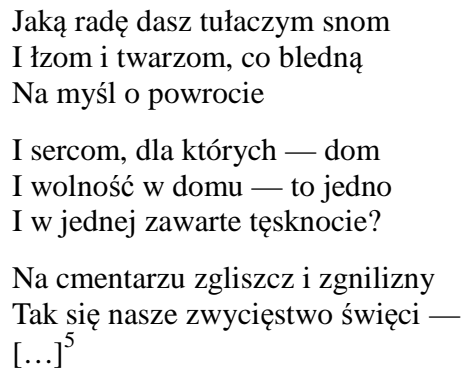

Podobne poczucie gorzkiego zawodu, przekonanie, iż wysiłek zbrojny żołnierza polskiego okazał się bezowocny i bezcelowy, przebija z tekstu Na pożegnanie ${ }^{6}$ Pawła Moskwy (brał udział w wojnie obronnej 1939 r., a po przedostaniu się na Wyspy Brytyjskie służył w lotnictwie wojskowym). Wiersz daje wiele do myślenia na temat pojęcia lojalności i jego praktycznego zastosowania w okresie tuż powojennym przez sprzymierzeńców w stolicy brytyjskiego imperium. Poruszająca jest bezpośredniość głosu poety, zachowana dzięki wypowiedzi potocznej, która bierze górę nad konwencjami języka literackiego:

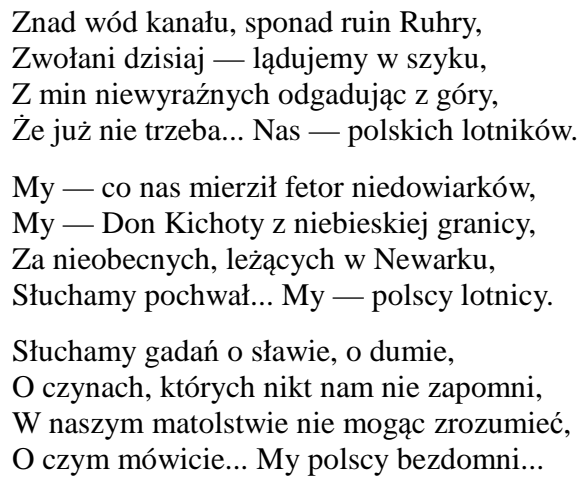

„Pierwsi w potrzebie”, ,niezrównani w boju” (I w naiwności, której nikt nie zmierzy)

Zbieramy od was, w godzinę pokoju,

Ochłapy glorii... My — polscy frajerzy! ${ }^{7}$

Ta przewidziana dla obiegu popularnego poezja dawała zapewne wyraz odczuciom sporej części emigracyjnych czytelników.

Temat repatriacji pojawia się w jednym z epizodów Czarnej koronki Mariana Czuchnowskiego, powieści, w której koleje losu głównej postaci nawiązują w czytelny sposób do biografii autora. Epizod ów wprowadza ostrą wymianę zdań między Andrzejem Morzysarną — więźniem Berezy i sowieckich łagrów, ewakuowanym z Armią Polską na Bliski Wschód i stamtąd przeniesionym służbowo do wojennego Londynu,

${ }^{5}$ M. Hemar, Poezje zebrane. Wrzesień 1939-maj 1945, oprac. A. K. Kunert, Łomianki 2006, s. 493-494.

${ }^{6}$ P. Moskwa, Air mail. Wiersze, [b.m., England 1947].

${ }^{7}$ P. Moskwa, Wiatr nas nosi po świecie. Antologia polskiej poezji żotnierskiej na obczyźnie 1939-1945, przedmowa A. Międzyrzecki, wyb., oprac., noty B. Klimaszewski, wstęp i współpraca W. Ligęza, Kraków 1993, s. 193. 
a przebywającym również w tym mieście inżynierem Makutrą, który zamierza urządzić się w Polsce, zapoznawszy się z plikiem komunistycznych broszur i ulotek propagandowych zachęcających do „,budowy ojczyzny, wznoszenia gmachu, zabliźniania ran”. Morzysarna, patrzący trzeźwo, bez złudzeń na powojenną rzeczywistość polityczną kraju, nie rokującą pomyślnego dla demokracji biegu wydarzeń, nie szczędzi inżynierowi drwin, ponieważ ten oznajmia, powołując się na wspomniane broszury i druki ulotne: „Gwarantują wszystkim pracę, pomoc i przebaczenie, braterską dłoń”.

- Pomoc, pracę, braterską dłoń, wszystko to znam. Trzy lata mi wystarczyło. Takie rzeczy, jak zegarek albo kalesony, powinieneś mieć pan tam przykute do ciała na łańcuchu. Tak samo buty z cholewami. Przynajmniej ich panu nie zdejmą podczas snu. Tylko za dnia. Razem z głową. To jeszcze też rozumiem. Ale co panu przebaczają? Niejasny punkt $^{8}$.

Ze zrozumieniem przyjmiemy gryzącą ironię Czuchnowskiego, jego ostrzeżenie przed niebezpieczeństwami czyhającymi na powracających do Polski, po przeczytaniu fragmentu książki Władysława Andersa Bez ostatniego rozdziału (Newton 1949); chodzi o zawarte w nim wystąpienie ministra Ernesta Bevina w Izbie Gmin z 20 marca 1946 r.:

Rząd JKM od wielu miesięcy nalegał na polski Rząd Tymczasowy, by ujawnił warunki, na których podstawie żołnierze będą mogli wracać. Obecnie osiągnięto porozumienie $\mathrm{z}$ polskim Rządem Tymczasowym i postaraliśmy się o wydanie oświadczenia w języku polskim, skierowane do każdego członka Polskich Sił Zbrojnych. Żołnierze otrzymają je dzisiaj ${ }^{9}$.

A jak to porozumienie przedstawiało się od strony Warszawy? Przytaczam słowa generała Andersa:

Nazajutrz po oświadczeniu ministra Bevina rozgłośnia warszawska ogłosiła:

„Celem uniknięcia jakichkolwiek nieporozumień stwierdza się na podstawie informacji

kół zbliżonych do Ministerstwa Spraw Zagranicznych, że rząd nie składał żadnego oświadczenia w sprawie postawy rządu wobec żołnierzy polskich, którzy chcą powrócić do Polski, ani co do warunków, jakie czekają ich po powrocie".

W komunikacie tym była również taka wzmianka:

„Bevin bierze na siebie ochronę Polaków w Polsce”,10.

Część uchodźców, wcale liczna, stanowiąca emigrację z wyboru - bezradna i zrezygnowana - nie miała odwagi szukać dróg prowadzących do kraju ze względów pozapolitycznych, czysto subiektywnych.

Wracać tam? Ziemia cicha, liście brzóz opadłe, wątłe zboża i pełne boleści wieczory -

Jakże nam wskrzesić życie w ruinach umarłe? -

Uśmiechnę się i powiem po angielsku: sorry. -

Powyższe zniewalające szczerością (można powiedzieć także: poczuciem trzeźwości) i bardzo pesymistyczne wyznanie znalazło się w wierszu Józefy Radzymińskiej O powrocie trudnym ${ }^{11}$.

\footnotetext{
${ }^{8}$ M. Czuchnowski, Czarna koronka. Powieść, Londyn 1966, s. 275.

${ }^{9}$ W. Anders, Bez ostatniego rozdziatu. Wspomnienia z lat 1939-1946, Lublin 1992, s. 431-432.

${ }^{10}$ Tamże, s. 433.

${ }^{11}$ Przyptyw. Poeci 2 Korpusu, do druku przygotował J. Bielatowicz, Rzym 1946, s. 93. Poetka brała udział w działalności konspiracyjnej AK i walczyła w powstaniu warszawskim; po
} 
O tym, jak wyglądało przystosowywanie się żołnierzy Armii Polskiej, a także przybyszów z obozów, dawnych urzędników biur wojskowych, akowców, do codzienności uchodźczego bytowania, opowiada Danuta Mostwin w bogatej w spostrzeżenia obyczajowe kronice powieściowej Dom starej lady (Londyn 1958).

$\mathrm{Z}$ powieści tej, opartej w dużej mierze na własnych przeżyciach pisarki ${ }^{12}$, dowiadujemy się, że po wielu latach służby, po rozmaitych przejściach na frontach i w niewoli, wyżsi oficerowie (bo głównie oni znaleźli się w polu widzenia autorki) udają się na kursy rzemieślnicze, gdyż taki jest rozkaz dowództwa PSZ. Próbują stać się szewcami, tapicerami, cukiernikami, licząc na to, że zdobycie praktycznego zawodu pozwoli im pozostać w Anglii, Walii, Szkocji, zapewnić sobie i rodzinie skromne środki utrzymania. Są i tacy, którzy kupują na kredyt zrujnowane posesje; doprowadzają je własnymi siłami do stanu używalności i wynajmują pokoje. W lepszej sytuacji znajdują się oficerowie rezerwy, podoficerowie i żołnierze, w większości mający kwalifikacje fachowe zdobyte jeszcze w Polsce. Teraz, rozchwytywani przez pracodawców, obierają sobie jako karierę zawodową malarstwo pokojowe, murarkę, stolarstwo...

Znaczna grupa cywilów o rodowodzie wojskowym, ta, której nie dopisało na emigracji szczęście, zmęczona zastępczą, dokuczliwą w swej tymczasowości egzystencją, skazana na status obywateli drugiej kategorii, nie akceptowana przez ksenofobicznie nastawionych Anglików (nieraz dosięgają ją z ich strony słowa: „Go back to your country”), zaczyna narzekać na okropny angielski klimat — i zastanawiać się podczas spotkań w Klubie Białego Orła, czy nie należałoby wyruszyć w świat w poszukiwaniu bardziej przyjaznego miejsca osiedlenia ${ }^{13}$. No i po staraniach i zabiegach umożliwiających zamieszkanie w kraju uznanym bądź uchodzącym za najlepszy z dostępnych, gdzie można by osiąść na długie, bezpieczne lata ${ }^{14}$, rozjeżdża się z rojeniami o przyszłości, niesprecyzowanymi nadziejami:

Jechali do Australii i Kanady, Argentyny i Wenezueli, do Brazylii i Afryki, we wszystkie zakątki Ameryki Północnej. Pozostawali w Londynie, w małych miasteczkach angielskich, szkockich i walijskich, we Francji i Italii, w Szwecji, Norwegii, Indiach, w Niemczech i Szwajcarii. Docierali do miejsc nieznanych, do zakątków egzotycznych, głodni przygody, nieświadomi, że unoszą w sobie zarazek choroby, która pożerać ich

kapitulacji dostała się do niewoli niemieckiej i przebywała w obozach jenieckich. W kwietniu 1945 r. jako pracownica PCK wyjechała do Włoch, a w 1946 do Anglii. W roku 1948 przeniosła się do Argentyny i zamieszkała w Buenos Aires.

${ }^{12}$ Problematykę socjologiczno-psychologiczną pisarstwa beletrystycznego Danuty Mostwin omawiają M. Stępień (Trzecia wartość. O twórczości Danuty Mostwin, Kraków 2000) oraz J. Pasterska (Trwanie w polskości. Emigranci wobec wyzwań życia na obczyźnie na przyktadzie prozy Danuty Mostwin, [w:] Powrześniowa emigracja niepodległościowa na mapie kultury nie tylko polskiej, pod red. V. Wejs-Milewskiej i E. Rogalewskiej, Białystok 2009, s. 829-842).

${ }^{13}$ Godzi się zacytować w tym miejscu wyimek z książki R. Habielskiego Niezłomni, nieprzejednani. Emigracyjne „Wiadomości” i ich krag 1940-1981, Warszawa 1991, s. 103: „Przeobrażeniom ulegał stosunek do byłych sojuszników, który z pełnego uniżenia i kompleksów w czasach wojny, przeradzał się w zdecydowanie niechętny. «Klimat, mgła, 'ciśnienie', wyłączność angielska, brzydota ulic, nuda publicznych lokali... nikt tego nie przeklął bardziej dosadnie niż Polacy» — zauważył Ferdynand Goetel” (Polski Londyn, Wiadomości 1953 nr 18, s. 1).

${ }^{14}$ Tę stronę procesu osiedleńczego opisuje R. Habielski (Życie społeczne i kulturalne emigracji, s. 41-55). Cytuję wprowadzające w temat zdanie ze s. 41: „Wpływ na migracje Polaków w okresie powojennym, oprócz decyzji podejmowanych przez zainteresowanych, miały rządy branych pod uwagę państw, rząd polski w Londynie oraz organizacje międzynarodowe (UNRRA, a później IRO)”. 
będzie i spalać, aż staną się jak liście jesienne nawiane obcymi wiatrami na obce pola i drogi ${ }^{15}$.

Wydziedziczeni ze swej ojczyzny, nie pozbędą się już obezwładniającej nostalgii za utraconymi okolicami dzieciństwa i młodości, niepowtarzalną wartością tego, do czego się przyzwyczaili przed wybuchem wojny; nie uwolnią od melancholijnych, budowanych ze strzępków pamięci, wspomnień czegoś, co jest dalekie i nierealne, i co bezpowrotnie minęło. Znamienna jest tonacja listu jednej z drugoplanowych bohaterek, która po opuszczeniu Anglii osiadła z mężem w Argentynie:

Kochani moi! Im dalej, tym tęskniej nam do Was. Pięknie tu, pięknie, słonecznie, cieszę się wszystkim, ale wieczorem, jak sobie po tym zgiełku dnia usiądę sama, to mnie taka żałość za serce chwyta, a widzę, że i Lucio też i Stefcio... chociaż się przed sobą nie przyznajemy. Bo powiedzcie, gdzie nam będzie dobrze na świecie, gdzie ${ }^{16}$

Ojciec narratorki, oficer przedwrześniowy, zabierający się w drogę do Stanów Zjednoczonych, nie traci najważniejszego dlań punktu orientacyjnego na mapie: wierzy, że podejmie marsz zwycięski ku Polsce. Wyjaśnia najbliższym, dlaczego pakuje do kufra swoje mundury: nie przestał być żołnierzem, mogą wezwać go w każdej chwili. „To tylko urlop, moi drodzy, to tylko krótkie zawieszenie broni!"17

Pozostańmy jeszcze przy tych wychodźcach wojskowych, którzy pozostali w Wielkiej Brytanii. Zajrzyjmy do nacechowanego reportażową lapidarnością tomu $O$ żotnierzu ciułaczu (Londyn 1955) Janusza Kowalewskiego.

Narrator i bohater w roli głównej (alter ego autora ${ }^{18}$ ), przedwojenny dziennikarz - obdarzony nieprzeciętnym zmysłem obserwacji i cenną umiejętnością plastycznego odtwarzania szczegółów, a także dostrzegania tego, co zabawne — w cyklu opowiadań „emigracyjnych”, tej partii książki, w której ukazuje swoje oblicze człowieka zaciętego i pochmurnego, chwyta się dorywczych zajęć (są to lata „na dorobku” — późne 40. i początki 50.): zmaga się ,,z workami mąki, szczotkami, kubłami, kotłami i brytfannami" ${ }^{19}$, zmywa talerze; pracuje w kuchni, cukierni, nawet w betoniarni, później otrzymuje zatrudnienie jako housekeeper i przeżywa codzienną udrękę z lokatorami kamienicy czynszowej. Mógłby zdobyć wygodną posadę listonosza, gdyby był rodowitym Brytyjczykiem - nieważne dla urzędnika biura pośrednictwa pracy jest to, że Polak bił się jako żołnierz brytyjskiej 8 . Armii. Nie pogardza wprawdzie pracą fizyczną, broni go przed tym jego przedwojenne zaangażowanie w skrajnie lewicową działalność polityczną, nie może jednak pogodzić się z nieprzewidzianymi skutkami takiej pracy (wtedy, kiedy jest nadmiernie wyczerpująca i pozbawia czasu wolnego na równolegle biegnące życie prywatne). Jako inteligent nie może także przystać na zubożające go duchowo przebywanie w towarzystwie ludzi ze środowisk o drastycznie zaniżonych dążeniach i aspiracjach. Ostatni utwór z cyklu „emigracyjnego” kończy się optymistycz-

${ }^{15}$ D. Mostwin, Dom starej lady, Baltimore-Toruń 2006, s. 91 („Pisma. Saga polska”, 5).

${ }^{16}$ Tamże, s. 204.

${ }^{17}$ Tamże, s. 205.

${ }^{18}$ Janusz Kowalewski po układzie Sikorski-Majski dotarł z obozu pracy na północnym Uralu do Armii Polskiej w Uzbekistanie. Brał udział (jako szeregowy) w kampanii włoskiej 2. Korpusu i został odznaczony za waleczność pod Monte Cassino. Po wojnie, przeniesiony z Włoch do Anglii, został skierowany do Polskiego Korpusu Przysposobienia i Rozmieszczenia. W roku 1946 zamieszkał w Londynie.

${ }^{19}$ W. Jaworski, W szerszym kontekście. Spóźnione uwagi o książce Janusza Kowalewskiego, Wiadomości $1972 \mathrm{nr}$ 30, s. 4. 
nie — nasz bohater, John otrzymuje stypendium z Polskiego Komitetu Edukacji Polaków w Wielkiej Brytanii i skierowanie na studia do szkoły handlowej.

W Sprawie Jessy - tekście zamykającym zbiór sentymentalnych, zaciekawiających egzotyką czasu bezpowrotnie minionego, opowiadań Podróż do Braiłowa Ireny Bączkowskiej, urodzonej i wychowanej na wsi, na Ukrainie — porucznik Jerzy odrzuca perspektywę emigracyjnej stabilizacji w Szkocji, ponieważ nie umie żyć bez Polski. Godzi się na przerzucenie go do kraju — i ginie w powstaniu warszawskim. Jego przyjaciel, też porucznik, przed rokiem 1939 urzędnik Izby Skarbowej, a później burmistrz, zmuszony w Londynie do pracy poniżej zdobytych kwalifikacji, dziurkuje i odbiera bilety na stacji kolei podziemnej. Trudno w tym momencie nie przywołać przepojonej sarkazmem konkluzji puentującej narrację: „No i cóż, jeden miał szczęście i zginął od razu, drugi nie miał szczęścia, to wszystko sprawa losu"20. Do dydaktycznego przesłania Sprawy Jessy krytycznie odniosła się Barbara Toporska:

Ukochaną wadą Polaków jest tzw. „narodowy instynkt samobójczy”. Kto weń nie wierzy — bluźni. Nie mam ochoty się narażać, przeciwnie: chciałabym się przysłużyć, żeby $\mathrm{z}$ tego gremialnego bicia się w piersi wyszło coś pożytecznego. Proponuję więc, żeby zacząć wreszcie walczyć z naprawdę groźną narodowej manii samobójczej odmianą — literackiego harakiri. Oto przykład.

W ostatnim opowiadaniu tomu Polak, porucznik rezerwy, zakotwiczony ze swoim pułkiem w Szkocji, potrzebny, lubiany, popularny, kochany, wbrew oporom swego dowódcy, wbrew interesom osobistego życia, wbrew przekroczonej czterdziestce, skacze na ochotnika do Polski... Zdaje się, że wystarczy? Nie, Bączkowska uważa, że jeśli morał nie będzie wyłożony, ofiara dla ojczyzny nie będzie pełna, więc wykłada. Porucznik składa coś w rodzaju patriotyczno-ideowej deklaracji na piśmie, zakończonej słowami:

„Wpływy, pradawne wpływy, które ciągnęły się wiekami, które kazały hetmanowi Żółkiewskiemu napisać ten list pod Cecorą, ciągnęły się za mną wiekami”.

Mieszko I jest więc pewnie odpowiedzialny za knocenie dzisiejszej literatury ${ }^{21}$.

Lepiej wiedzie się - do pewnego czasu - wojskowym ze zbioru opowiadań Drugi rzut Czesława Dobka. Oto kapitan artylerii, Wierkolski, znalazłszy stałą przystań w Anglii, dorobił się nowoczesnej, przynoszącej niezły dochód pralni; innemu oficerowi, który dosłużył się tej samej rangi, udało się jedynie przyuczyć do fachu krawieckiego; marynarz Kamodny, ożeniony z Angielką, jest właścicielem firmy w Londynie, zajmującej się burzeniem starych domów (akcja dzieje się w latach 60.). Dobek poświęca także nieco uwagi robotnikom, przeważnie sprowadzonym z Niemiec dipisom, ale także byłym żołnierzom, którzy przeszli przez formację PKPR. Wszyscy oni zatrudnieni zostali w Szkocji przy przebijaniu tuneli dla elektrowni napędzanych wodą.

Mimo bardzo ciężkiej pracy i trudnych warunków życia w niezbyt dobrze zorganizowanych obozach, wielu szło do tunelu ze względu na wysokie zarobki sięgające 20 funtów tygodniowo (zarobek robotnika niewykwalifikowanego wynosił wówczas około 5 funtów)

— czytamy w nocie autorskiej dołączonej do tekstu „Free Country”22.

Na marginesie warto dodać, że zdobyte przez wychodźców polskich wykształcenie, stopnie wojskowe i stanowiska nic nie znaczyły również w Australii (otworzyła

\footnotetext{
${ }^{20}$ I. Bączkowska, Podróż do Braiłowa, Londyn [1959], s. 231.

${ }^{21}$ B. Toporska, Powiesść świetna, ale niedokończona, Wiadomości $1960 \mathrm{nr}$ 27, s. 3.

${ }^{22}$ Cz. Dobek, Drugi rzut i inne opowiadania, Paryż 1968, s. 84.
} 
ona dla Polaków swoje granice w roku 1947) ${ }^{23}$. Może jeden przykład. W opowieści (dziennikiem podszytej) Andrzeja Chciuka pt. Smutny uśmiech, odnotowującej zwyczajne zdarzenia dnia powszedniego, pojawia się wzmianka o niejakim Januszu Tężyłowiczu, byłym majorze NSZ, żołnierzu powstania warszawskiego, który otrzymał zatrudnienie jako „robotnik na nocnej szychcie na plancie szlifierek u Holdena” ${ }^{24}$.

Egzystencję typowej społeczności polskiej, składającej się z rodzin przybyłych z Bliskiego Wschodu, Afryki, Indii i Niemiec, osadzonej po burzach wojennych na pograniczu Anglii i Walii, przedstawia Janina Kowalska (właśc. Hanna Maria Świderska) w książce o zakroju epickim, zatytułowanej właśnie tak: Pogranicze ${ }^{25}$. Autorka - cytuje jej wypowiedź ze Stowa wstępnego - ,spędziła dwanaście lat w hostelach i obozach w różnych częściach Wyspy i dotąd czuje w kościach ich klimat” jako ,jedynego w swoim rodzaju zjawiska w emigracyjnej socjologii”. Kontekst interpretacyjny tego utworu (jego miejsce na mapie literackiej) zarysował przekonująco Bogdan Czaykowski:

Tematycznie powieść Kowalskiej można by postawić obok Trans-Atlantyku Gombrowicza, Katedry Sandwiczów (stanowiącej pierwszą część Turystów z bocianich gniazd) Straszewicza czy pisanej w języku angielskim powieści Pietrkiewicza Future to Let. Wszystkie one drążą w jakimś stopniu, każda na swój sposób, problem polskości, polskich obciążeń, przywar i cnót, i wszystkie czynią to w zestawieniu z obcymi społecznościami, na obcej ziemi. Wszystkie zawierają elementy satyry, parodii i groteski.

Opowieść Kowalskiej różni się jednak zasadniczo od wyżej wymienionych utworów swoim charakterem realistyczno-dokumentarnym ${ }^{26}$.

Pewne jej ogniwa narracyjne stylizowane są, jak zauważył Czaykowski, na epos heroikomiczny. Niepodobna teraz zająć się tą kwalifikacją gatunkową w sposób bardziej wyczerpujący, niechże więc potwierdzeniem sądu krytyka, a zarazem cząstkowym wskazaniem możliwości ekspresyjnych (estetyczno-aksjologicznych) przywołanej formy rodzajowej będzie przytoczenie wyimka z zajmującego mnie teraz tekstu:

Przy tym chudym bezrobociu Crowley ze wzmożoną pasją oddaje się hazardowi, ale uprawia go pocztą, i tylko najpoważniejsi myślą o sprawach polskich, korzystając z nadmiaru wolnego czasu, by uzupełnić swe militarne wykształcenie i nie zostać w tyle, gdy nadejdzie Chwila Dziejowa. A nadejść może lada moment, przecież w amerykańskim Kongresie mówi się o odrzuceniu Jałty, a nawet przeznacza fundusze na tworzenie wśród uchodźców armii wyzwolenia. Nic dziwnego, że najbardziej patriotyczna część Crowleyu śledzi wypadki z najwyższym zainteresowaniem i boleje, że brak gotówki nie pozwolił jej wziąć udziału w wielkich manewrach na terenie opustoszałego obozu „gdzieś” w Midlandach. Dojazd kosztowny, a zresztą nie mają samochodów ani motorów, tak pożądanych w tej imprezie do zastąpienia czołgów przy ćwiczeniu ruchów tak-

${ }^{23}$ A. Racięski (Nasze drogi w Australii 1947-1977, Hobart 1978, s. 39) podaje, że ogółem w latach 1947-1952 przybyło do Australii około 3,7 tys. polskich żołnierzy, w tym 800 z Wielkiej Brytanii i 2,5 tys. z Niemiec (jeńców wojennych z września 1939 r., akowców i uczestników powstania warszawskiego). Na opracowanie to powołuję się za B. Żongołłowicz ( $O$ pót globu od domu. Obraz Polonii australijskiej w twórczości Andrzeja Chciuka, Toruń-Melbourne 2007, s. 17).

${ }^{24}$ A. Chciuk, Smutny uśmiech. (Opowiadania), Paryż 1957, s. 19.

${ }^{25}$ Autorka we wrześniu 1941 r. po ogłoszeniu amnestii wynikłej z układu Sikorski-Majski opuściła wraz z rodziną miejsce zesłania na Syberii i znalazła się w formującej się w ZSRR Armii Polskiej (ojciec wcześniej wstąpił do wojska). W roku 1942 została przerzucona do Persji (Iranu). Następnie dotarła do Palestyny, skąd wyjechała w 1947 do Anglii. Tu mieszkała w obozach przejściowych dla Polaków.

${ }^{26}$ B. Czaykowski, Wypisz, wymaluj. Pionierskie poczatki emigracji w Anglii, Kultura 1982, nr 9(420), s. 141. 
tycznych. Dlatego bez udziału Crowleyu uczestnicy wojennej gry zapoznali się z broniami atomowymi i rolą kawalerii $w$ nowoczesnej wojnie, $i$ to zapoznali na własnej skórze, bo podczas dwugodzinnej akcji w te dziurawe baraki i burzany walnęły trzy atomówki typu Hiroszima i potem ekipy sanitarne długo zbierały rannych, którzy zdołali ujść z życiem. Straty w ludziach wyniosły tylko $42,2 \%$, co w wojnie atomowej należy uznać za wynik nader pozytywny, jak później podkreślono w dyskusji sztabowej, która odbyła się, gdy żywi, ranni i polegli zasiedli do żołnierskiego obiadu. Podkreślono, jak doskonały duch panuje $\mathrm{w}$ naszych szeregach i jednomyślnie postanowiono opracować, usystematyzować i przekazać do Kół Studiów Wojskowych polską terminologię nowoczesnej wojny i broni jądrowych, bo na polu prawdziwej bitwy nie będzie czasu jej wyjaśniać i drogo nas to może kosztować ${ }^{27}$.

Nie ulega wątpliwości, że działanie normy gatunkowej eposu bohaterskiego zostało tu w sposób prowokacyjny obniżone; zarazem wydaje się rzeczą oczywistą zwłaszcza jeśli uwzględnić cały układ wątków fabularnych książki Kowalskiej — iż mamy do czynienia $\mathrm{z}$ deheroizacją, której towarzyszy sympatia i dobroduszna wyrozumiałość dla organizacji życia w środowisku crowleyowskim. Dopowiedzieć należy jeszcze, że groźba bomby atomowej była obsesją pierwszych lat powojennych, nie tylko w Anglii.

Pora przejść do utworów opisujących przeżycia imigrantów, którzy postanowili opuścić Wielką Brytanię i osiąść za Atlantykiem. Za materiał źródłowy może posłużyć powieść Ameryko! Ameryko! (Paryż 1961) Danuty Mostwin, wiernie oddająca rzeczywistość społeczną pierwszego etapu oswajania się jednej z polskich rodzin z obcym kontynentem.

Józefa i Helenę Żuławskich, córkę Bogę, jej męża Andrzeja Baska, syna Wojciecha i jego żonę Ewę witają na nabrzeżu nowojorskim smukłe drapacze chmur Manhattanu i neony obiecujące wolność, pracę, dobrobyt. Wkrótce wszakże czar pierwszego kontaktu $\mathrm{z}$,wolną ziemią Waszyngtona” wyparty zostaje przez poczucie rozmijania się oczekiwań z rzeczywistością: brak american experience uniemożliwia podjęcie zarobkowania zgodnego z własnymi zainteresowaniami i ambicjami. W bezlitośnie obojętnej przestrzeni wielkiego miasta nasi imigranci czują się wyizolowani i opuszczeni; jedynie w kręgu rodzinnym — i wśród części znajomych Polaków, strzegących własnej grupowej jedności — odzyskują poczucie bezpieczeństwa.

Generacja najstarsza wychodźców - stopniowo, w miarę rozwoju fabuły, autorka wprowadza w tok zdarzeń także inne postaci z polskiej społeczności — otóż generacja ta próbuje przystosować się do warunków życia w Ameryce, licząc na swe wykształcenie i zalety charakteru. Przekonuje się jednak szybko, że w USA z rezerwą podchodzi się do posiadanych przez nią predyspozycji i skazuje na deklasację zawodową i materialną. Broniąc się przed całkowitym odrzuceniem, garnie się do organizacji i stowarzyszeń pozwalających na utrzymanie przedemigracyjnej tożsamości, a w prywatnych kontaktach zachowuje przedwojenne tytuły zawodowe i stopnie wojskowe. Pułkownik Józef Żuławski otwiera „lanczenetę”, ale w dzielnicy stopniowo opuszczanej przez białych i zasiedlanej przez kolorowych mieszkańców, co skazuje go na niepowodzenie w gastronomicznym przedsięwzięciu. Ale nie powoduje to zejścia Żuławskich z traktu wiodącego do akceptacji życia w Stanach Zjednoczonych: kupno zaniedbanej farmy i życzliwość amerykańskich wiejskich sąsiadów, którzy przyszli im z nieoczekiwaną pomocą, staje się doświadczeniem prowadzącym do odkrycia lepszej strony tego kraju i wydobycia się z emigranckiego wyobcowania; USA stają się miejscem oswojonym, przybierającym oznaki stałości. Przystosowywanie się do warunków egzystencji

${ }^{27}$ J. Kowalska, Pogranicze, Paryż 1980, s. 155-156. 
uchodźczej, odzyskiwanie stabilizacji w nowym środowisku, wydaje się w świetle powieści Mostwin czymś koniecznym i naturalnym.

Najwięcej miejsca zajmują w utworze sprawy przedstawicieli pokolenia średniego, również poruszających się w obrębie takiego postrzegania rzeczywistości, jaki wyznacza ich „pamięć biograficzna”. Mowa o Andrzeju i Bodze, Wojciechu i Ewie; oni łatwiej przyswajają sobie amerykański styl życia, lecz i dla nich zejście z obranej w młodości drogi nie jest pozbawione problemów; im także nieobca jest świadomość bolesnej nieprzystawalności sytuacji, w jakiej się znaleźli, do wcześniejszych marzeń o karierze zawodowej i wyznawanego świata wartości.

Zechciejmy zatrzymać się tu w ramach męsko nacechowanej przestrzeni i zauważyć, że Andrzej, porucznik rezerwy, zasłużony na polach bitew, po wyższych studiach, lecz bez dyplomu, żyjący z poczuciem straty i niespełnienia, nie przestaje rozmyślać o swej przeszłości wojennej. Z tego, co można wyczytać z jego myśli zarejestrowanych w monologu wewnętrznym, wynika, iż być może wolałby być w dalszym ciągu na froncie niż zmagać się z powojenną codziennością amerykańską, która przekreśla w jego staraniach o pracę zarobkową - żołnierską odwagę i męstwo. Porucznik Wojciech, z zawodu inżynier, w latach wojny kurier polityczny Polskiego Rządu w Londynie, również w USA wybiera „służbę dla dobra ojczyzny” (później ją porzuca): jako nieodłączny towarzysz prezesa Stronnictwa i stypendysta Radia Wolna Europa bierze udział w dyskusjach, które ogniskują się na sprawach polskiego interesu narodowego, jego politycznej suwerenności. Ale niech przemówi Boga (Danuta Mostwin naznaczyła świadomość bohaterki elementami własnego rozeznania w kwestii trwania struktur politycznych wychodźstwa niepodległościowego):

Siedziało ich kilkunastu, pomiędzy nimi Andrzej; przejęci, zaczerwienieni, podobni z daleka do starej ryciny, którą zapomnienie i czas zatrą, a historyk po obejrzeniu odłoży razem z innymi dokumentami do teki Polskiej Emigracji w Stanach Zjednoczonych. Jakże ważni wydawali się sobie, nierozpoznani, zapomniani w stolicy Ameryki.

„,...Łączymy w ten sposób wysiłki nasze w walce o wolność, niepodległość, o demokrację i sprawiedliwość społeczną, o postęp i pokój...”.

Boga słuchała, widziała ich poprzez uchylone drzwi. Myślała: Jesteście ludźmi, smutnymi, samotnymi ludźmi, którym obcięto korzenie ${ }^{28}$.

Pokolenie najmłodsze szybciej wrasta w nowe cywilizacyjne otoczenie i nie przeżywa dylematów związanych $\mathrm{z}$ rozchwianą identyfikacją narodową. Odchodzenie od rodzimej tradycji, gustów i wizji świata pokolenia starszego, jest dla niej naturalnym procesem - i wszelkie zbyt mocne przeciwstawianie się temu biegowi rzeczy zdaje się być skazane na niepowodzenie. Do takiego wniosku dochodzi Andrzej w rozmowie z żoną, kiedy myśli o przyszłości swych synów: „- - To nieuniknione, będą Amerykanami polskiego pochodzenia. Odziedziczą szerokie spojrzenie na świat, instynkt walki, sympatię dla Polski”,29.

Dzieci przeciwstawiają się rodzicom, na siłę utrzymującym je w swoistym izolacjonizmie etnicznym, w opowiadaniu Danuty Mostwin Córki, które pomieszczone zostało w jej tomie Asteroidy (Londyn 1965). Młodsza z dziewcząt, odczuwająca należną wiekowi dorastania potrzebę zaznaczenia swej odrębności, zapowiada, że natychmiast po ukończeniu college'u zerwie z otaczającym ją w domu „schizofrenicznym" nastawieniem do powojennej rzeczywistości i weźmie ślub z Amerykaninem. Starsza wybierze na męża prawdopodobnie Polaka, porucznika, ale i jej nie podobają

\footnotetext{
${ }^{28}$ D. Mostwin, Ameryko! Ameryko!, Baltimore-Toruń 2004, s. 81 („Pisma. Saga polska”, 6).

${ }^{29}$ Tamże, s. 113.
} 
się wzorce społecznych zachowań rodaków na obczyźnie, dla których czas jakby zatrzymał się w miejscu, co znajduje wyraz w ich odwoływaniu się do miar i norm, nawyków i postaw, charakterystycznych dla minionej, bo zakończonej wybuchem wojny, epoki.

Dobrze ułożą się stosunki między ojcem i synem (ale nie od razu) w powieści Czesława Dobka Skała nad jeziorem (Londyn 1969). Pułkownik Jerzy Kuna z 2. Korpusu, nie wrócił do Polski z powodów osobistych: jego sympatia, na emigracji obiekt romantycznej tęsknoty, w trzecim dniu powstania warszawskiego została wraz z innymi mieszkańcami zabrana $\mathrm{z}$ domu na Woli i wszelki ślad po niej zaginął. Ożenił się z Margaret, swą byłą pielęgniarką, która opiekowała się nim, gdy go przywieźli z Włoch do szpitala dla polskich żołnierzy w Szkocji. Otrzymał pracę w fabryce jej ojca (tylko tyle, bo był za dumny, aby cokolwiek z cudzych rąk przyjąć). Ma syna George'a, nie rozumiejącego ani słowa z języka jego dzieciństwa i teścia walczącego z nim o miłość dziecka, jako że Macdonald chce wychować chłopca na Brytyjczyka, przyszłego właściciela prowadzonego przez siebie przedsiębiorstwa. Formą samoobrony przed powikłaniami uczuciowymi, narastającym poczuciem odosobnienia w niesprzyjającym klimacie rodzinnym (ma dobrą, kochającą żonę, z którą wszelako o wielu sprawach nie potrafi rozmawiać) stają się dla pułkownika — zawsze zdyscyplinowanego i trzymającego się w ryzach — niedzielne samotne wyprawy na skałę nad jeziorem, gdzie odzyskuje spokój w kontemplacji górskiego krajobrazu. Nie utrzymuje łączności ze swymi rodakami: odsunął się od polskiego Komitetu Obywatelskiego skupiającego kombatantów, ponieważ nie znalazł z nim porozumienia na gruncie politycznym, nie mógł także znieść presji katolickiego proboszcza, który wytykał mu, że jako Polak zawarł związek małżeński z ewangeliczką i posłał syna do szkoły protestanckiej.

Tę trudną sytuację podwójnego osamotnienia: zarówno w interakcji z drugim człowiekiem, jak i w kontaktach z lokalną społecznością polską, zmienią - i w domu, i w Komitecie Obywatelskim — odwiedziny przyjaciela z czasów przedwojennych, późniejszego towarzysza broni w 2. Korpusie, a po wojnie kolejno — powróćmy na chwilę na udeptaną ścieżkę deklasacji socjalnej — górnika w Kanadzie, sprzedawcy w sklepie w Buenos Aires, kierowcy ciężarówki (w końcu jednak redaktora i autora książki wspomnieniowej). Przede wszystkim zbliżą one George’a do Jerzego: chłopak po zapoznaniu się z drukami reklamowymi podarowanymi mu przez gościa, zachęcającymi do odwiedzin Polski i zainteresowania się jej pejzażami i kulturą, odrzuca perspektywę zaplanowanej przez dziadka wakacyjnej podroży po Morzu Śródziemnym i postanawia wybrać się na wycieczkę do kraju rodzinnego swego ojca. Powiedział dziadkowi, ,że musi to zobaczyć, bo inaczej do końca życia nie będzie wiedział kim jest, gdzie jest jego miejsce pod słońcem"30.

W odmienny, dotkliwy sposób przebiega proces adaptacji do nowych warunków życia na obczyźnie w wypadku syna uchodźców polskich w mikropowieści Czesława Dobka Na ratunek gotębicy. Jej główny bohater, Tadeusz Samek staje przed sądem przysięgłych w Londynie, niewinnie — jak się później okaże — oskarżony o zabójstwo swej narzeczonej Joanny Poranek, polskiej emigrantki. Wypowiedzi oskarżyciela i obrońcy z urzędu, ojca i matki oraz powołanych świadków tworzą wielogłos służący rekonstrukcji jego życiorysu, znajdują też kompozycyjny kontrapunkt w postaci rozłożonego na części monologu wewnętrznego bohatera; monolog ten, przełamujący się w strumień świadomości, o strukturze czasowej zestawiającej teraźniejszość z przeszłością, deszyfruje jego okaleczoną, dotknięta atrofią uczuć osobowość.

${ }^{30}$ Cz. Dobek, Skała nad jeziorem. Powieść, Londyn 1969, s. 143. 
Ojciec Tadeusza przybył z wojskiem do Wielkiej Brytanii w roku 1940. Tadeusz urodził się w czasie wojny w ,tiepłuszce” podczas transportu do Kazachstanu, dokąd została zesłana jego matka. Samek-senior zobaczył swe ośmioletnie dziecko dopiero w 1948 r., kiedy jego żonie udało się przedostać do Anglii z Afryki Wschodniej z armią generała Andersa. Zamieszkał z rodziną zrazu w obozie przejściowym, a następnie w Nottingham. Syn uczył się w szkole angielskiej i robił wystarczające postępy. Pozornie wszystko zdawało się układać pomyślnie. A jednak Tadeusz trzykrotnie uciekał z domu, szukając dachu nad głową u obcych ludzi, ponieważ ojciec bił go bezlitośnie. Po którejś z rzędu awanturze domowej, znikł z pola widzenia rodziców i pojawił się w Londynie w schronisku dla polskiej młodzieży. Podjął pracę i wrócił do szkoły. W tydzień po egzaminach znowu ślad po nim zaginął - wyłowiony z Tamizy, wymyśla sobie własne ponowne narodziny w wieku 19 lat z nowych rodziców, zaczyna żyć pod nazwiskiem William Loneman, obracając się wyłącznie wśród młodych ludzi z londyńskiego półświatka (przebywają w nim także zepchnięci do podziemia homoseksualiści) ${ }^{31}$.

Uzasadnione będzie pytanie, dlaczego ojciec katował syna? Ano dlatego, że ten nie lubił pracy fizycznej i nie chciał wziąć się do jakiejś ,,pożytecznej roboty”; że wykazywał zamiłowanie do nauki i niewłaściwych książek (romansów, a nie historii o Kościuszce czy cudzie nad Wisłą), a ponadto nie miał zamiaru oddawać ojcu całego swego zarobku. W toku konfrontacji sądowej wychodzi na jaw, iż Samek-senior z synem nie mogli dojść do porozumienia w jeszcze jednej sprawie. Mówi matka o Tadeuszu:

On nie chciał być Polakiem. On tylko po angielsku. Angielskie książki, angielska mowa, angielscy koledzy. Jakże to być mogło? Ojciec zasłużony żołnierz, patriota, zawsze na polskich uroczystościach, w kaplicy pieniądze zbierał na tacę, a syn ani po polsku, ani do kościoła. [...] Na odznaczenia ojca pluł ${ }^{32}$.

Co mogło zrazić młodego mężczyznę do wspólnoty emigrantów, jej doświadczeń z lat wojny, do polskiego języka, narodowości, obyczaju, do szkoły sobotniej, do polskich rodziców? Brutalność ojca barbarzyńcy, usiłującego, tak jak mu na to pozwalało jego sumienie, sprostać zasadom formującym tożsamość zbiorową w jej tradycyjnym kształcie, zgodnym z niepisanym etosem czy kodeksem owej wspólnoty? Z całą pewnością też. Ale może i młodzieńcze podświadome pragnienie utrzymywania więzi z ludźmi nie obciążonymi pamięcią wojennej poniewierki? Za Simone Weil powiedzieć by należało: „Istota ludzka ma korzenie, jeśli rzeczywiście, w sposób aktywny i naturalny uczestniczy w egzystencji wspólnoty przechowującej jakieś skarby przeszłości i obdarzonej poczuciem jutra"33. Tadeusz Samek nie dostrzegł widocznie ,poczucia jutra" w otoczeniu polskim, a w każdym razie nie znalazł oparcia w rodzinie. Było mu ono zapewne szczególnie potrzebne jako człowiekowi chorobliwie małomównemu i skrytemu, na co wpływ mogły mieć okrutne przejścia wczesnego, kazachstańskiego i afrykańskiego, dzieciństwa. Dla uzasadnienia moich domysłów sięgam po książkę Bogdana Czaykowskiego i Bolesława Sulika. Zawiera ona wyniki analizy społecznych

${ }^{31}$ T. Kaliściak uważa, iż Na ratunek gotębicy jest ,jedną z nielicznych powojennych powieści (obok Trans-Atlantyku Gombrowicza czy Bram raju Andrzejewskiego) otwarcie podejmujących problematykę homoseksualną" i że problematyka ta „wydaje się centralna dla narracji”; zob.: T. Kaliściak, Zapomniana powieść o „cudaku” [on-line]. [Dostęp: sierpień 2011]. Dostępny w WWW: http://www.homiki.pl/modules.php?name=News\&file=article\&sid=4169.

${ }^{32}$ Cz. Dobek, Na ratunek gotębicy, Londyn 1964, s. 131.

${ }^{33}$ S. Weil, Zakorzenienie, [w:] tejże, Wybór pism, przeł. Cz. Miłosz, Warszawa 1983, s. 247. 
postaw emigrantów zamieszkałych w Wielkiej Brytanii w latach 1958-1960. Autorzy tej pracy dowodzą:

Nienormalność społeczności takiej, jak emigracja polska w W[ielkiej] Brytanii polega na wielu czynnikach. Jednym z nich jest fakt, że jest ona czymś w rodzaju mniejszości narodowej, ale bez własnych korzeni w historii narodu, którego stała się składową częścią. Jej korzenie znajdują się gdzie indziej: w kraju rodzinnym, w jego historii i tradycji, które próbuje kontynuować w warunkach niezbyt sprzyjających, w oderwaniu od konkretnego podłoża, na którym wyrosły. Aby zachować swoje wartości i odrębności, społeczność ta próbuje się zamknąć we własnym świecie, żyć przeszłością (i ewentualnie przyszłością), walczyć o utrzymanie stanu posiadania, unikać innowacji i stwarzać atmosferę egzaltacji wokół ideałów, dla których stała się emigracją, przy okazji idealizując to, co do sfery idealnej nie należy lub należeć nie musi ${ }^{34}$.

Utrwalony przez powojenne uchodźstwo styl życia na obcej ziemi, oparty na pielęgnowaniu wspomnień o wojennych przejściach i wynikającej z nich odpowiedzialności za przyszłość — odrzuca młodzież z powieści Janiny Kowalskiej, rozluźniająca więzi $\mathrm{z}$ crowleyowskim zaściankiem. Wzrastając w środowisku polsko-angielsko-walijskim, zdobywa wiedzę o rzeczywistości, która pochodzi już z innego porządku niż ten, którego strzegli jej kresowi ojcowie; skupia się wokół wartości stwarzanych przez aktualne wymogi życia społecznego i standardy kulturowe kraju zamieszkania, nowych obyczajów, zachowań, norm współżycia i współdziałania.

Młodzi i ruchliwi, nie żadne Ofiary Wojny, a przy tym nie obwieszeni rodziną, co ciągnie na dno jak młyński kamień i z braku forsy trzyma w Crowleyu, opuszczają obóz i ciągną do miast, gdzie fabryki i złoto na ulicy, i do ośrodków wiedzy, bo dla jednych lepsza przyszłość przyjdzie przez zakłady naukowe, a dla drugich przez zarobek. [...] Bywali w świecie pouczają tych, co z Crowleyu rwą się do miast, żeby szukając kwatery unikali Polaków jak jasnej cholery, bo mało jest takich, co człowieka nie obedrą ze skóry za lada jaką ciemną norę z odrapanymi gratami i sfałszowanymi licznikami do elektryki i gazu. Stąd wychodźcy z Crowleyu unikają rzeczy rodackich: organizacji, podniosłych akademii i tradycyjnych opłatków, a ich jedyny kontakt ze sprawą polską ogranicza się do mszy, gdzie idzie się oglądać ludzi i zadawać szyku, oraz potańcówek, by popatrzeć na panny i kawalerów: kupił — nie kupił. [...] Co ich obchodzą rozgrywki skarbowców z mikołajczykami albo rodzicielskie wspomnienia o domkach i gospodarkach utraconych na rozległych terenach Rzeczypospolitej między Niemnem a Dniestrem? ${ }^{35}$

Ten passus dowodzi, że świat, o którym opowiada autorka — w sposób daleki od przyjętych w opisach emigranckiego bytowania stereotypów (ważna jest tu nie polityka, lecz egzystencja, życie innymi słowy) — został odtworzony także na poziomie języka: z odwołaniem się do rejestru niskiego polszczyzny, typowej mowy na co dzień (ordinary speech), co daje czytelnikowi pełniejsze wyobrażenie o walorach Pogranicza jako rzeczywiście swoistego studium socjologicznego.

Rozwijając w dalszym ciągu wątek żołnierskich losów i związanych z nimi życiowych przeprowadzek, nie można nie zając się opowiadaniem Pomiędzy wilki (z tomu Karabela z Meschedu) Ksawerego Pruszyńskiego, opublikowanym w kraju, ale wyrosłym z refleksji politycznej niedawnego żołnierza, który wojował na dostępnych mu frontach $^{36}$ i pełnił określone funkcje polityczne w ekipie generała Władysława Sikor-

${ }^{34}$ B. Czaykowski, B. Sulik, Polacy w W[ielkiej] Brytanii, Paryż 1961, s. 521.

${ }^{35}$ J. Kowalska, Pogranicze, s. 104-105.

${ }^{36}$ W 1940 r. brał udział w kampanii norweskiej w szeregach Brygady Podhalańskiej jako dowódca drużyny w stopniu kaprala podchorążego i został odznaczony Krzyżem Walecznych; 
skiego, a bezpośrednio po zakończeniu działań wojennych, przejściowo - emigranta. Pisarz powrócił do kraju 10 września 1945 r., posłuszny patriotycznemu obowiązkowi, który kazał mu znaleźć się w ojczyźnie i wziąć udział w usuwaniu śladów zniszczeń, a także błędów i zaniedbań przedwojennej polityki sanacyjnej, żywił bowiem nadzieję, że Polska po wojnie stanie się państwem demokratycznym i wolnym. Został zatrudniony w służbie dyplomatycznej.

A zatem sięgnijmy do wskazanego tekstu.

Bezimiennego bohatera Battle of Britain, dzielnego dowódcę dywizjonu RAF, spotkało karne przeniesienie na stanowisko drugiego zastępcy attaché lotniczego Ambasady RP w Waszyngtonie za urządzoną w jednostce demonstrację sprzeciwu wobec „słów niegodnych brytyjskiego honoru”, jakie padły z ust ,wielkiego alianckiego męża stanu", kiedy dyskusja w czasie debaty parlamentarnej zahaczyła o sprawę polską. Na emigracji wewnętrznie wypalony z powodu bankructwa nadziei pokładanych w wysiłku militarnym, który — w wyniku zakulisowych machinacji dyplomatycznych — nie przeważył szali wydarzeń na korzyść jego ojczyzny, trzyma się z dala od nowojorskiego getta, pozostałego po tzw. „obozie londyńskim”, jako że olbrzymia jego część przez wolność i niepodległość kraju rozumie powrót do rządów przedwrześniowych. W Kanadzie zawrze znajomość z urodzonym na Syberii rosyjskim traperem — oficerem z I wojny światowej, białym emigrantem od lat siedemnastu (,Miał jedną z tych leśnych, typowo kanadyjskich posad w obsłudze lasów, które zapewniają swobodne krążenie po obszarze równym co do wielkości przeciętnym europejskim państwom"37), weźmie rozbrat z tym wszystkim, co do tej pory składało się na jego własne życie, i zaszyje się — idąc śladem Rosjanina - w ciemnej głuszy puszczy „pomiędzy wilkami”. Ta nowa przestrzeń przypomni mu swym kojącym nerwy spokojem i pierwotnym pięknem strony rodzinne (okolice Rymanowa w Beskidzie Niskim), tak jak niegdyś Rosjaninowi - Syberię, i przywróci wyczekiwany porządek bytu, zaburzony przez wojnę. Co do Beskidu Niskiego — takie imaginacyjne podróże do krainy wspomnień i wyobraźni, dokumentujące najgłębsze uczucia przywiązania do miejsc utraconych, odbywał niejeden emigrant, aby odzyskać samego siebie, zaspokoić tęsknotę za swoją młodością. Lektura tekstu Pruszyńskiego pozwala dojść do przekonania o słuszności obserwacji poczynionej swego czasu przez Jerzego Stempowskiego:

Być sobą, być sobą — his above all, mówi Poloniusz - można, zdaje się, tylko w ja-

kiejś więzi; konkretnej czy idealnej, ze swoją rzeką, z krajobrazem swojej ściślejszej ojczyzny, rodzonej czy przybranej ${ }^{38}$.

Przed powzięciem brzemiennej w skutkach decyzji, oznaczającej zgodę na życie odpowiedzialne z własnego wyboru, surowe i twarde, pilot zwierza się swej amerykańskiej kochance, Denis (Pomiędzy wilki to również ciekawa, zbudowana z retrospekcji opowieść o jego dwóch miłościach; pierwsza przypadła na okres międzywojenny i zbliżyła go do młodej żony generała, wysokiego patrona jego szkoły podchorążych lotnictwa w Warszawie):

Całym moim życiem tych siedmiu lat jestem związany najbliżej, najściślej z tymi na

w roku 1944 bił się w 1. Dywizji Pancernej w trakcie ofensywy aliantów w Normandii, za co ponownie przyznano mu Krzyż Walecznych.

${ }^{37}$ K. Pruszyński, Pomiędzy wilki, [w:] tegoż, Karabela z Meschedu, Warszawa 1957, s. 273. Pierwsze wyd.: Warszawa 1948.

${ }^{38}$ J. Stempowski, Dziennik podróży do Austrii i Niemiec, Rzym 1946; cyt. z: tenże, Od Berdyczowa do Lafitów, wyb., oprac. i przedmową opatrzył A. S. Kowalczyk, Wołowiec 2001, s. 88. 
Zachodzie. Zwłaszcza z tymi, których już dziś nie ma. To był wielki czas, tych lat siedem, wielki i mocny, i wiem, że takiego czasu niektórzy ludzie nigdy nie mają w życiu, a nikt nie ma go drugi raz. [...] Od nich nigdy nie odejdę. Ale żyć na emigracji z nimi nie będę także, bo to już nie jest i nie będzie to, co było, i to jest całkiem coś innego i to nie jest nic. [...] Na emigracji tęskniłbym za krajem takim, jaki pamiętam. W Polsce tęskniłbym za tym, co zostało za mną: ludźmi bliskimi i latami przeszłymi. Nie miałby ze mnie pożytku nikt ${ }^{39}$.

Na ocenę poczynionych przezeń kroków może i musi zdobyć się sam czytelnik, wziąwszy pod uwagę także zalecenie ,,pewnego znajomego doktora, rodem z Wiednia, zagnanego jeszcze «Anschlussem» do Stanów Zjednoczonych”. Wskazał on — za pośrednictwem Denis - egzulowi obciążonemu „chorobą” wojenną i emigracyjną niezawodny, jego zdaniem, środek leczniczy:

Będzie nim powrót do kraju. Przestanie żyć niezdrowym, beztlenowym powietrzem wspomnień wojennych, wejdzie w życie swego własnego społeczeństwa. „Ze wszystkiego, co słyszę dobrego i złego o obecnej Polsce — mówił doktor — jedno wynika niezbicie, że życie tam jest niezmiernie silne, żywiołowe, gwałtowne, mocne, mocniejsze nawet niż śmierć, jaką mu zadać chciano. Wejście w to życie będzie dla niego ożywczym wstrząsem. Ono go uzdrowi" ${ }^{40}$.

Rzecz ciekawa: moc perswazyjna fachowej porady psychoanalityka wyraźnie słabnie, jeśli odnieść ją do sytuacji, w jakiej znalazł się bohater opowiadania W Giewałdowej (ogłoszonego drukiem w zbiorze Karabela $z$ Meschedu). Porucznik Tomasz (bo jego dotyczy ta dygresja) po powrocie z Anglii, ,nie mógł politycznie ani życiowo, ani w żaden inny sposób odnaleźć wspólnego języka"41 ze spotykanymi w Polsce ludźmi.

Przypomniał sobie pierwsze dni po przybyciu, Warszawę, drogę z Warszawy, Kraków. Rozmowa następowała po rozmowie i każda się zacinała. Pamięta, pytał go jeden major, dlaczego właściwie wrócił i jakie ma zamiary, i kogo znał na emigracji? Pamięta słowa: „No, w y ś c i e wojnę przegrali”. Pamiętał znajomego: „No, ale pan miał szczęście, nie każdemu tak było, wy londyńczycy w ogóle jesteście szczęśliwcy, ale to, że pan przyjechał, to pan frajer; nie mógł się pan w Kanadzie jakiejś urządzić?"

Toteż zaczyna myśleć - wpływ ma na to także niespodziewany, spowodowany wojenną rozłąką, rozpad małżeństwa - o wydostaniu się ze swej podhalańskiej wsi do Wielkiej Brytanii. Zetknięcie się z wiejskimi osieroconymi chłopcami, do których dotarła już jego sława żołnierska i którzy powiadomili go o swej przynależności do ochotniczego „oddziału Armii Krajowej powiatu nowotarskiego”, sprawi jednak, iż pozostanie w Giewałdowej. Poczuje się cywilem, „rozbroi” ich oddział, kierując do nich słowa: „Wróciłem, kiedy trzeba było wrócić. [...] Tak samo trzeba było wrócić, jak wtedy trzeba było iść. [...] Odtąd nie ma AK. Teraz jest szkoła. Rano pójdziecie do szkoły"43. Sam zajmie się edukacją chłopców; uzna to za swą obywatelską powinność wobec gromady.

Pod koniec opisanej historii Pruszyński dla dopełnienia swego ideowego przesłania odwoła się do motywów mitologicznych funkcjonujących od wieków w kulturze euro-

\footnotetext{
${ }^{39}$ K. Pruszyński, Pomiędzy wilki, s. 277.

${ }^{40}$ Tamże, s. 258.

${ }^{41}$ K. Pruszyński, W Giewałdowej, [w:] Karabela z Meschedu, s. 294.

42 Tamże, s. 291.

${ }^{43}$ Tamże, s. 313.
} 
pejskiej. Oto Tomasz — już wychylony ku najbliższym dniom w kraju — wybrał się ze swymi pozyskanymi uczniami nad rodzinną rzeczułkę na raki...

W tym właśnie miejscu Łężna swym zakolem podmywała szeroko grunt i była głębsza, ciemna i chłodna. Porucznik zanurzył się z wolna w ten jej ciemny i chłodny nurt. Ostrożnie, ręką odwykłą, szukał podwodnie nor i zakamarków, z których kiedyś, chłopak jak tamci, wyciągał szamocące się niezdarnie skorupiaki. Nim jednak ręką trafił, oblał go nurt rzeki swojej, najbardziej swojej, zimny, zmywający wszystko, uzdrawiający, wracający siły, spokój i moc. Nurt był wartki bardzo, jakby się spieszył, aby obmyć to wszystko, co było i co narosło, i aby wygładzić to wszystko wodami zapomnienia. I Tomaszowi, nauczycielowi szkoły powszechnej i oficerowi broni pancernej, przyszedł naraz na myśl Odys do swej skalistej wracający Itaki i ów strumień z wierzeń Hellady, który toczył wody letejskie ${ }^{44}$.

Wytłumaczenia dokonanego przez Tomasza wyboru można doszukać się w wypowiedzi Karola Estreichera, współpracownika rządu emigracyjnego, współautora wielu wstępnych artykułów londyńskiego miesięcznika „Nowa Polska” (pismo subwencjonowane było w pierwszej fazie istnienia przez rząd Władysława Sikorskiego). Mówił Estreicher:

W chwili śmierci gen. Sikorskiego było oczywiste, że rozwiązanie spraw polskich przyjdzie ze Wschodu, z ZSRR. W styczniu 1944 r. Ksawery Pruszyński rozpoczął na lamach „Nowej Polski” druk Margrabiego Wielopolskiego. Miejsce refleksji o kształcie ustrojowym przyszłej Polski zastąpiło przekonanie, że trzeba myśleć o formie korzystnej dla nas ugody z nowym porządkiem. Akceptacja linii Curzona stała się faktem. Przestała być teorią. Przegrana wszystkich orientacji obozu londyńskiego była oczywistością.

Pamiętam — był to początek 1945 r. — jakąś konferencję w gronie emigracyjnym. Patrzyłem na obecnych i miałem uczucie, że wszyscy mamy podniesione kołnierze i wracamy do domu. Ideologia pracy w kraju stała się naturalnym, co więcej — jedynym — rozwiązaniem. Tę zmianę sytuacji i potrzebę zmiany postaw należało uzasadnić.

Wołały już nie sprawy wojenne ani praca w konspiracji, ale praca codzienna w warsztacie i szkole ${ }^{45}$.

Wichura wojenna i powojenne losy rzuciły do Kanady lotników z opowiadania Po Akademii, wydrukowanego w tomie Sosny i palmy Bolesława Pomiana Piątkowskiego (autor latał jako nawigator w RAF Ferry Command). Wprowadzenie do wspomnieniowego toku narracji zaczyna się tak:

Sala zastygła w słuchaniu. Dawno przebrzmiały ostatnie tony. Pianista zdjął ręce z klawiszy, a znieruchomiali słuchacze zdawali się wciąż jeszcze łowić ostatnie echa dźwięków. Aż ktoś pierwszy otrząsnął się z uroku melodii, ze świata czarów wrócił do rzeczywistości i złożył ręce do oklasku. Zahuczał grom. Na estradzie, na tle dekoracji przedstawiających ruiny Warszawy, stał pianista i ukłonami dziękował za owację.

Akademia zbliżała się ku końcowi. Były mowy, uchwały, cześć artystyczna. Byli zaproszeni goście. Biskupi, ministrowie, generałowie. Nastrój był uroczysty i podniosły.

Siedzący obok mnie Staszek wymownie pukał palcem w dłoń: szopkę.

— Tu mi palma kokosowa wyrośnie, jeśli jeszcze kiedyś dam się namówić na taką

Siedzący obok Staszka Karol spojrzał na dłoń Staszka, potem na swoje własne, namulone fizyczną pracą ręce:

— Ta sama stara obłuda. Tłuści i syci przemawiają za głodnych i chudych. Żywi

\footnotetext{
${ }^{44}$ Tamże, s. 314-315.

${ }^{45}$ K. Estreicher, Próba realizmu, rozmawiał A. Jagodziński, Więź 1974 nr 6, s. 120.
} 
i zażywni sławią bohaterstwo tych, co już dawno zdążyli zgnić w bezimiennych dołach

Trzask odsuwanych krzeseł, tupot stawianych twardo nóg, chrzęst prężących się postaci. Z estrady płyną dźwięki butnej, bojowej piosenki, która przeszła z ziemi włoskiej do Polski i stała się hymnem narodowym.

Karol miał dar wyrażania głośno tego, o czym inni myśleli po cichu:

- Szkoda już się rozchodzić, znów upłyną miesiące zanim się razem zejdziemy, a może by tak do Picadilly Baru?

Siedzimy — grupka średnio starszych panów — i pociągamy wiskacza.

$[\ldots]$

Miła atmosfera picia i beztroski. Skupiliśmy się ciasno wokół stolika. Wokół nas morze obcych głosów, obcych ludzi, obcego obyczaju ${ }^{46}$.

„Grupce średnio starszych panów” (w czasie wojny służyli w brytyjskich siłach powietrznych) na ogół powiodło się za oceanem. Niektórzy odnieśli nawet jakiś sukces materialny (Karol ma „własny dom, własny samochód, własne przedsiębiorstwo”), mimo to dręczy ich myśl, że — jak to wyraził inny członek „emigracyjnej załogi” — jest coś nie w porządku w tym, że muszą oddawać swe siły i wiedzę na rzecz przybranej ojczyzny, pracować dla niej, a nie dla rodzinnej ziemi mazowieckiej. Czują potrzebę zasięgnięcia w tej materii czyjejś opinii, podzielenia się z kimś swym ciężarem; chcieliby wiedzieć, co o ich położeniu, o ich poczuciu krzywdy i nieprawdopodobnej dziejowej niesprawiedliwości, sądzą mówcy, którzy wystąpili na akademii — niestrudzeni, zawsze gotowi do uwzniośleń, jak można wnosić ze wstępnej partii opowiadania, celebransi uroczystości narodowych.

W pamięci Karola utkwiło mocno jedno wydarzenie: w Lagos zetknął się księdzem Leclerque'em, który przybył tam z Lyonu jako młody kleryk jeszcze przed I wojną światową i pozostał - a po wielu latach zyskał szacunek i zaufanie miejscowej ludności. Karol zwrócił się do niego z wyrazami uznania, co wywołało niespodziewaną reakcję:

Uważam księdza za jednego z tych nielicznych ludzi, którzy umierając będą mogli powtórzyć słowa św. Pawła o dobrym potykaniu się i o dochowaniu wiary.

Pamiętam tę chwilę jak dziś. Twarz księdza posmutniała, znikł uśmiech, który ją zazwyczaj ozdabiał. Oczy księdza stały się smutne.

- Mylisz się, synu. Moje życie było pomyłką. Bóg nikomu nie każe opuszczać swojej ojczyzny ${ }^{47}$.

Atmosferę patriotycznej egzaltacji polskich kombatantów z II i I wojny, osiadłych w Belgii oddaje Marian Pankowski w jednej z sekwencji quasi-powieści poetycko-groteskowej Matuga idzie (Bruksela 1959). Rozdział Wjazd Tego przedstawia uroczystość wbicia gwoździ w sztandar „Związku byłych bijących się o Słuszną Sprawę”. Obrzęd narodowy odbywa się w upalne wakacyjne popołudnie. Polacy, poczuwający się do historycznego obowiązku zachowania i przechowania ducha wolności na obczyźnie, tłumnie pojawili się na placu miejskim, skąd — to ważne — „wychyliwszy się nieco, można było dostrzec wrogą flagę wrogiej ambasady”. Przemówienie, jakby spisane z kart Trans-Atlantyku, wygłasza „wszystkim znany major” nie istniejącej już armii:

— Koleżanki i koledzy! Zanim nadjedzie Ktoś, od kogo zależy wszystko. Ktoś, komu rzucimy pod stopy naszą gehennę tułaczą, zanim nadjedzie Ktoś, dla kogo słowo Walka, słowo Czyn, słowo Naród, słowo Ziemia, słowo Wódz, słowo Nigdy, słowo...

${ }^{46}$ B. Pomian Piątkowski, Po Akademii, [w:] tegoż, Sosny i palmy. Opowiadania, Londyn 1968, s. $157-158$

${ }^{47}$ Tamże, s. 165-166. 
zresztą koledzy i koleżanki, darmośmy krew przelewali? O tośmy się bijali? Po tośmy się tułali i tułamy? Za żadne skarby, koleżanki i koledzy. Ani piędzi. A kiedy przyjdzie potrzeba..., a kiedy znowu stanąć nam przyjdzie... staniemy, jak mur krwi, koleżanki i koledzy, jak szaniec! ${ }^{48}$

Po drugim wystąpieniu - Wielkiej Osoby (Tego, który przyjechał), utrzymanym w stylu zużytych, pustych deklaracji — do przepychających się w tłumie uczestników zgromadzenia docierają zresztą jedynie strzępy jego wypowiedzi - i po odśpiewaniu Roty: „Zaległa cisza. Wszyscy chcieli coś robić, żeby nawiązać do życia, ale życia nie było. Jak długo trwał śpiew, był chociaż śpiew. Gdy minął śpiew, naszła ich pustka"49. Groteska sprowadza tu patetyczny teatr historii do wymiaru zdarzeń peryferyjnych, małych i śmiesznych: polskość jako przynależność do wspólnoty narodowej, przechodząca w przestrzeń fantazmatów komunikacyjnych (słów, haseł, obrazów, które upraszczają rzeczywistość, zawężają jej różnorodność), broniąca z dala od kraju coraz bardziej uszczuplającego się stanu posiadania, staje się — tak jak w powieści Gombrowicza rolą wynikającą z układu solidarności, do której rodacy wzajemnie się przymuszają.

W rok po ukazaniu się książki Pankowskiego, której ostrze krytyczne w relacjonowanym powyżej epizodzie wymierzone zostało, jak widać, w stronę emigracji politycznej $^{50}$, pisał Czesław Miłosz: „Kpiny z niezłomnych emigracyjnych wodzów i ceremonii narodowych w Brukseli [...] oznaczają, że szarganie świętości należy już do powszechnie przyjętych obyczajów”, i myśl swą uzupełnił spostrzeżeniem: „Okazy Polusów, obieżyświatów i łazików przypominają nieco ich niezrównany prototyp lite-

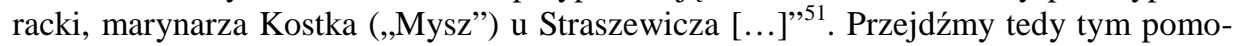
stem zbudowanym przez poetę w stronę Katedry Sandwiczów (stanowiącej pierwszy segment fabularny książki Turyści z bocianich gniazd, wydanej w Paryżu w 1953 r.).

Czesław Straszewicz kreśli sylwetki polskich marynarzy, którzy wylądowali na urugwajskich antypodach i zatrzymali się na jakiś czas w Punta Chata (czytaj: Montevideo). Marynarze ci to - by posłużyć się frazą Wacława A. Zbyszewskiego „«suchoputnoje moriaki», jak się obrazowo mówi po rosyjsku, rodzaj spieszonej kawalerii, słowem, wilki morskie na lądzie, i to bez posady, bez grosza, bez kraju, żyjący z powietrza, z paru groszy prezesujących rodaków, z kantu i paserstwa [...]" ${ }^{, 52}$. Owe „wilki morskie" ciągną za sobą cienie traumatycznych doświadczeń lat wojny i wygnania - jak Kostek Napierski ${ }^{53}$, najsilniej wyodrębniony z ich grupy, z zapadłym w głąb pamięci syberyjskim wspomnieniem o siostrzyczce, którą jako czternastoletni chłopak po śmierci rodziców, zagrzebanych w śniegu, niósł z Krywoj Dieriewni w kierunku Polszy, karmił „w drodze wielomiesięcznej” kradzioną mąką i kaszą, i w końcu po-

${ }^{48}$ M. Pankowski, Matuga idzie. Przygody, Lublin 1983, s. 100-101.

${ }^{49}$ Tamże, s. 108.

${ }^{50}$ Wyraźnie naruszając związane z jej statusem tabu, autor (który notabene nigdy nie uważał się za klasycznego emigranta) zmuszony był opublikować Matugę własnym nakładem w liczbie zaledwie 519 egzemplarzy.

${ }^{51}$ Cz. Miłosz, Diariusz paryski: Matuga z kacetów, Kultura 1960 nr 3(149), s. 20.

${ }^{52}$ W. A. Zbyszewski, Straszewicz, Wiadomości 1954 nr 22, s. 2.

53 Zdaniem B. Gutkowskiej (Czestawa Straszewicza apologia przypadku. O „Turystach z bocianich gniazd", [w:] Presja i ekspresja. Zjazd szczeciński i socrealizm, pod red. D. Dąbrowskiej i P. Michałowskiego, Szczecin 2002, s. 279) nazwisko to ma w powieści nacechowanie ironiczne: z Aleksandra Kostki Napierskiego „w 1951 roku szukająca swej genealogii komunistyczna władza uczyniła walczącego z klasowym wyzyskiem ludowego bohatera". W roku 1953 ukazała się zarysowująca sylwetkę tego przywódcy ruchu chłopskiego na Podhalu w XVII wieku, zgodnie z socrealistyczną wersją przeszłości, książka Jalu Kurka Nad Czorsztynem się błyska. 
chował, nie dotarłszy do ziemi rodzinnej; napomykają w rozmowach o swych okupacyjnych dziejach w akowskiej partyzantce — jak szef Jan Bolesławski, jeden z pięciu uciekinierów z ss. „Feliks Dzierżyński”, którzy postanowili wyzwolić się z opresji systemu komunistycznego. O Korybucie Dusznym, przedwojennym marynarzu z „Sobieskiego”: „Wiadomo było, że wojnę przebył na północy, na statku, który zaopatrywał bazy alianckie. Wiadomo też było — niektórym, że na północy miał grube nieprzyjemności, które na głowę mu padły i w życiu przeszkadzały" ${ }^{34}$.

W odróżnieniu od miejscowego „starego” wychodźstwa, „turyści”, niepewni swej chwiejnej egzystencji, zbierają się na pogawędki tudzież zwierzenia w portowym barze „Tango” i Domu Polskim, oczekując zamustrowania na statki pływające pod obcymi banderami. Jeśli chodzi o Kostka, to zdobywa się on na szczególny typ inwencji: ceni sobie jak największy skarb zdobytą gdzieś książkę kucharską — „odwieczną polską konstytucję", stara się też na jej podstawie dowieść wyższości rodzimych dań nad potrawami urugwajskimi, toteż popisuje się w najbliższym gronie marynarzy i portowych panien swymi kulinarnymi umiejętnościami. „Konstytucja” ta, zniżona siłą rzeczy do poziomu iluzorycznej pociechy, jest dlań dowodem kulturalnego górowania Polski nad innymi narodami. W ten sposób odnosi się po swojemu — wszystko zdaje się na to wskazywać - do niepodległościowych zobowiązań moralno-patriotycznych emigracji, do postulatu wypełniania przez nią misji wytrwania przy polskości ${ }^{55}$. Lizus Jarząbek z kolei, zaprzyjaźniony z Kostkiem — z którym łączy go pamięć wspólnych chwil przeżytych na obczyźnie i w miarę swoista zapobiegliwość — również daleki od przenoszenia wzorców zachowań publicznych w sferę prywatną, prawdopodobnie rozczarowany rezultatem wojny, który unieważnił sens jego walki na froncie, i powojennym osłabieniem zainteresowania zachodnich aliantów polskim sojusznikiem - nigdy nie zdradził, że ma ordery przyznane mu za bohaterską służbę na łodzi podwodnej.

Trzeba by w związku z tymi konstatacjami uwypuklić jeszcze jeden rys wizerunku Kostka Napierskiego: drażliwość na punkcie honoru zdradzonego przez sojuszników politycznych i militarnych wygnańca, kompleks niezawinionej krzywdy i utraty. Kostek leżał sześć miesięcy „,na łożu śmierci” w szpitalu w Anglii i raz na zawsze znienawidził „całą wyspę angielską,"56. Podobne nastawienie wzbudzają w nim Stany Zjednoczone, a okaże się to w trakcie zajścia, do jakiego doszło w barze za sprawą marynarza amerykańskiego, który nieopatrznie skierował się do polskiego stolika.

[Marynarz] Dopchawszy się — a chłop był pokaźny, niewiele mniejszy od Szefa — rozrzewnionym głosem wybulgotał spicz po angielsku.

Tej treści: - Polish! Z daleka poznałem, że Polish! Miałem Polów kamaradów na „Michiganie” first class, first class boyów. Przyszedłem wam tutaj dać shake hand, sha-

${ }^{54}$ Cz. Straszewicz, Turyści z bocianich gniazd, Warszawa 1992, s. 33-34.

$55 \mathrm{Nie}$ inaczej dbał o przetrwanie polskości Adam Mickiewicz, który nie rozstawał się z książką kucharską w czasie swych wojaży po Europie, odbywanych w towarzystwie Antoniego Edwarda Odyńca. Towarzysz podróży pisał w liście z Rzymu 28 kwietnia 1830 r.: ,Jutro zaś ma to być uczta czysto poetycko-panieńska. Adam radził wyprawić czysto polsko-litewską, i to podług starożytnych przepisów Doskonatego kucharza, to jest starej obdartej książki, którą jak co dobrego ma w podróżnej bibliotece swojej i odczytuje nieraz z wielką przyjemnością"; A. E. Odyniec, Listy z podróży, t. 2, Warszawa 1961, s. 300, cyt. za: I. Jarosińska, Kuchnia polska i romantyczna, Kraków 1994, s. 62.

${ }^{56}$ Cz. Straszewicz, Turyści z bocianich gniazd, s. 42. Autor w czerwcu 1940 r. dotarł do Anglii i w stopniu porucznika został przydzielony do stacjonującej w Szkocji 10. Brygady Kawalerii Zmotoryzowanej gen. Stanisława Maczka; zwolniono go z wojska po wypadku samochodowym. 
ke hand! Biedna ta Poland wasza! Czytałem w „Lifie”, że jest tragic, tragic! Dwieście lat pod Turkish occupation, sto lat Swedish occupation, dziesięć lat Napoleon's occupation i później German occupation. Tragic, Tragic! Teraz bolshevik occupation! Ale będzie liberation! Shake!

— Jezus, Maria, Lizus, lej go w mordę!

Mówiąc „lej”, Kostek sam przywalił. W brzuch strzelił z obu pięści, raz, dwa! Podskoczywszy pod brodę, raz, dwa! I w nos! Strzelał z obu pieści, jak sprzężony karabin maszynowy z dwóch luf.

Przyjaźnie usposobiony marynarz cofnął się rakiem pod barowy kontuar, tam rozkrzyżował się i utkwif ${ }^{57}$.

A co na usprawiedliwienie swej szarży ma do powiedzenia Kostek? Dowie się o tym Pani z Kiosku (w planie pozatekstowym żona Straszewicza), będąca dla polskich marynarzy, szukających jakiejś namiastki życia rodzinnego, „,biurem wywnętrzań czy też konfesjonałem" ${ }^{58}$ : „- Ja, proszę Pani, z polityką nic nie mam, ale mnie się akurat przypomniał ichniejszy ich prezydent, którego widziałem w kinie, jak siedział sobie zadowolony razem z dziadźką" ${ }^{\circ 9}$. Ta szarża, suwerenny gest jednostki wyrównującej rachunek z czasu wojny, ten wolny od retorycznej nadwyżki odruchowy protest z powodu ustępliwości Waszyngtonu wobec Moskwy, zdaje się świadczyć nader wymownie, że protagonista Katedry Sandwiczów nie liczy już na żadną zbrojną interwencję angloamerykańską w Europie, która mogłaby przynieść wyzwolenie Polsce, oddanej Stalinowi w Teheranie i Jałcie, i w rezultacie pozbawionej elementarnego i niepodważalnego prawa do samostanowienia. Wyjaśnienie Kostka przekazane Pani z Kiosku jest niewątpliwie prostolinijne, bezpretensjonalne, acz nie pozbawione finezji - i cokolwiek przejmujące.

\section{THE POST-WAR FORTUNES OF POLISH SOLDIERS IN THE WEST (IN THE LIGHT OF THE FICTIONAL CREATIVITY OF THE SECOND EMIGRATION WITERS)}

It is a review of prose and poetic works touching upon the problem of the fortunes of Polish soldiers after the end of World War II, particularly a transformation of war exile into emigration. The Author confronts the publications of D. Mostwin, M. Czuchnowski, I. Bączkowska, $\mathrm{Cz}$. Straszewicz and others, with historic documents, he mentions a social-economic situation of the characters of his narration, about environments in Great Britain, USA etc.

KEY WORDS: soldier emigration; Second Emigration; post-war fortunes of emigrants.

\footnotetext{
${ }^{57}$ Tamże, s. 60-61.

${ }^{58}$ Tamże, s. 76.

${ }^{59}$ Tamże, s. 62.
} 